\title{
Ancestor Worshiping Beliefs in the Beliefs and Religion Life of Vietnamese People: Nature, Values, and Changes of it in the Current Period
}

\section{Nguyen Trong Long*}

Ho Chi Minh University of Natural Resources and Environment, Ho Chi Minh City, Vietnam

\section{Vu Hong Van}

University of Transport and Communications, Hanoi, Vietnam

Correspondence: vhvan@utc2.edu.vn

\begin{abstract}
In all forms of folk beliefs, ancestor worship is a universal traditional belief form of the Vietnamese people. As a Vietnamese people, "everyone worships their ancestors, everyone worships their parents and grandparent". Ancestor worship is a common belief in the whole country. It is a belief that expresses the deeply humanistic spirit of the Vietnamese people and has great values in human life. So, what is the nature of ancestor worship? What is the values of ancestor worship in life? And in the context of globalization, how has this the belief changed? This study focuses on analyzing the above contents, thereby highlighting the value of this belief in the spiritual life of Vietnamese people; to point out the positive and negative changes of this belief in the current period; from that, take the right measures to bring into play the positive and limit the negative side of those changes in the spiritual life of Vietnamese people.
\end{abstract}

Keywords: folk beliefs; ancestor worshiping belief; spiritual life; beliefs and religion life; Vietnamese people; Vietnam today

\section{INTRODUCTION}

In all forms of folk beliefs, ancestor worship is a universal and traditional belief form of the Vietnamese people. As a Vietnamese, "everyone also worships their parents (deceased), everyone also worships their grandparents (deceased)" (Giau, 1973; Binh, 2005; Anh, 2005; Van, 2005; Van, 2019; Van, et. al, 2020). This is a fundamental cultural difference between Vietnam and other countries. West, where the spiritual life of people is predominantly Christian or Arab countries where Islam is the state religion (Roszko, 2012).

Vietnam is a nation's emotional, respectful, introverted people, often solving problems emotionally rather than rationally (Kim, 1919). The tradition of "when drinking water, remember its source" is one of the most respectable qualities of the Vietnamese people (Kim, 1919.

Vietnamese people tend to look back on the past and regret the past more towards the future like Westerners (Roszko, 2012). Therefore, Vietnamese people often retain their feelings of grief for their deceased parents. The Vietnamese ancestor worship practice was born on this basis and is regarded by the majority of Vietnamese as almost a religion, called grandparents worship (Anh, 2005).

Ancestor worship has become a traditional custom, has a very special place in the spiritual life of the Vietnamese people, and is one of the elements that make up the cultural identity of Vietnam. Ancestor worshiping belief is very simple: they believe that their ancestors are sacred, they go to eternity but still live next to their children and grandchildren, they bless their children and grandchildren when facing difficulties and difficulties; to rejoice when their children have good luck, encourage their children when they encounter good things and also rebuke them for doing evil, etc.

In Vietnam, ancestor worship is not only a popular belief among Kinh people - the majority of ethnic groups (85.3\%) (General Statistics Office, 2019), but also preserved in some other ethnic groups such as Muong people, Thai people, Chinese people, etc. Experiencing many ups and downs and events of history, while many other religions and folk beliefs have been subjected to uneasiness, convicted of "superstition" but ancestor worship has and still occupied a sacred position in the spiritual life of the Vietnamese. Consciousness "people have ancestors, have tones" is preserved in the spiritual realm and is passed down from generation to generation, whether they 
live in their own country or in exile in the country. In particular, this is a form of belief that has been respected and recognized by political institutions (the state) from past to present, albeit with different degrees. Along with the nation's historical process, this belief is the accretion, gathering precious moral values of the Vietnamese people.

Thus, in history and in the present life, ancestor worship has greatly affected people's life. Vietnamese and foreign scholars have had many opinions around this worship phenomenon (Anh, 2005; Binh, 2005; Roszko, 2012; Van, 2019). Is this some kind of belief or religion? Or is it just a custom, a habit, a cultural or ethical activity? Etc. To have a scientific basis to evaluate this phenomenon, it is necessary to clarify its origin and nature.

The origin and nature of this belief have been studied by many scientists around the world for a long time with profound explanations by many methods (Anh, 2005; Binh, 2005; Roszko, 2012; Van, 2019). This article is a contribution on the basis of research, comparison, comparison with other types of beliefs or religions to find out the true origin, nature and value of ancestral worship of Vietnamese people; at the same time pointed out both positive and negative changes in this belief before the effects of globalization.

\section{LITERATURE REVIEW}

When did ancestor worship appear? Up to now, there are many theories, it was formed during the Northern colonial period (around the early years of AD, Vietnam was invaded by feudal dynasties of China) (Dai Viet Su Ky Toan Thu, 1697), along with the influences of Han culture (Giau, 1973). But there are some issues that need to be discussed: Could the time of ancestor worship be born earlier? How is the relationship between the indigenous factor and the imported factor in forming this belief? Let's learn from the socio-cultural background of the Vietnamese community as well as the economic conditions for the socio-cultural development.

The first important basis for the formation of any religious beliefs is also people's spiritual conception of the world (Tylor, 2000). Like many other ethnic groups, the Vietnamese people come from the perception of "all living beings" - everything has a soul and starts from the natural world around them (Giau, 1973 \& 2003; Anh, 2005). Therefore, the oldest deity people worshiped are the nature gods, especially the god of the tree, the god of the mountain, the god of the river, etc. By the mythicalization way, the deities have been given a human face (gentle or fierce), human psychology (happy or angry). It can be said that the humanization of natural gods has created a transition for the formation of the anthropomorphic system (human god) (Giau, 1983; Hinh, 2007; Van, 2019). This is also the period when people begin to discover themselves. At a certain point, the relationship between the tangible and the invisible, especially life and death, preoccupied people. Still, with the concept of the spirit as mentioned above, they believe that in every human being there are "souls" and "purses".

There is no sublime sense of Christian heaven or hell or Buddhism's reincarnation, in folk perception, body and soul are both attached and separate. Soul and body stick together in life and separate at death, their bodies are merged with dust, but the existing soul changes to live in another world (Giau 1973; Ngoc, 2002). That negative realm has all the same needs as the earthly life. According to folk beliefs, death is also a form of "life" in another environment.

Folk believes that if the dead are not provided with sufficient material things (as in life), they will become "hungry ghosts", wandering, harassing the living. The "am" (the place of worship for the soul, the very small wall area) the sentient beings set up at the end of the village, or the Yulan Festival (the full moon of July) for the "ten sentient beings" are the expressions of wanting to share, consoling helpless, starving souls no people worship. A rather mysterious phenomenon but is trusted by people, that is "âm phù", the dead are suitable for the living. Many random phenomena have occurred related to the living and the dead relationships, making the resurrected person more confident in the help of the dead:

For example: When a family that has just died people, children in the family suddenly get promoted or promoted; or business is thriving, earning a lot of profit. Even children and grandchildren in the family 
have been married for many years, they cannot give birth, but $t$ after grandparents, parents who have just died, suddenly become pregnant again, giving birth to a son following the lineage, etc.

Thus, the relationship between those who live and those who die of the same bloodline is even closer. During the second or three generations, those are still very specific and profound memories. Grandparents and parents, even though they die, are always present in the minds of their children and grandchildren, and children always feel the responsibility both physically and mentally for them. The belief in death is just a return to meet ancestors, grandparents, and ancestors who may follow, bless the descendants, and have been the basis of ancestor worship.

In Vietnam, although all ethnic groups have ancestral conceptions and some ethnic groups have different forms of worship, according to many researchers, these forms, or customary worship to die in funerals, to provide items for burying the dead, to worship for a few years, or to leave a grave, etc. inconsistent with the traditional Vietnamese ancestor worship (continuous, long-term worship). Therefore, the similarities of this form of belief are most evident only in a few Southeast Asian countries, especially China (Giau, 1973).

The traditional Vietnamese society also has certain economic bases for the formation and maintenance of ancestral worship beliefs (Institute of History, 2007). First of all, it is a self-sufficient small farm economy. This is a favorable environment for the appearance of polytheism. From an economic standpoint, a Vietnamese village is almost an independent unit and likewise its cell - the small household. This is an important factor that holds members of the same generation and between generations. By extension, the residence families gathered with them, and many of them gathered into villages. Before the village, people did not exist as individuals, but in the name of family lineages - blood-related units. It can be said that the small farm economy is a favorable land for consolidating and developing the national consciousness as well as ancestral worship in the village.

In the economic aspect, there is an important point that makes a difference in ancestor worship in Vietnam and China (Vuong \& Tan, 1960). Due to the hot and humid tropical climate, monsoon, Vietnam produces wet rice according to the tradition of small farming combined with livestock. Therefore, production does not require largescale labor concentration as in the place of dry wheat production, production tools are also small, compact, light, all family members from women and children use easily. The inevitable combination of this process makes Vietnamese people stick with families, usually, nuclear families are more closely attached to the lineages (Ngoc, 2002; Van, et. al, 2020). Almost all families have an altar to their ancestors whether "thờ chính or thờ vọng".

At the stage of the patriarchal gens, the men began to hold control of the family because they had an important role in economic activities, their wives and children absolutely submitted to and respected the authority has been established, not only when they are still alive but also when they are gone (died) (Giau, 1973; Thu, 1997; Hinh, 2007; Van, 2019). The children bearing the father's surname have inherited the sense of authority, and is it true that the ritual of funerals and ancestral sacrifices are also "a form of reflecting the myth of patriarchal authority in a family" (Giau, 1983, p. 216).

Thus, ancestral worship belief was born and maintained in certain historical and social conditions. From the primitive community alliance to the primitive family linkage along the male bloodline has been a long history. Following the path of "sharing the same name on the father's side", small families bonded together as surnames. This is the type of exogamous unit because the members of the family are linked together by the same bloodline and the same ancestor.

Ancestor worship belief in Vietnamese people has been formed, existed, and developed on the basis of spiritual conception and a fairly stable socio-economic and ideological foundation (Giau, $1973 \&$ \& 1983; Binh, 2005). It can be said that the indigenous and rustic spiritual elements were institutionalized and legalized thanks to Confucian ideology and the support of the feudatory dynasties. Therefore, this belief has been preserved throughout the volatile history.

\section{RELATED CONCEPTS}

\section{The Belief}


According to the Han-Vietnamese Dictionary of scholar Dao Duy Anh (1998, p. 546)), belief is explained: "Superstition, admiration for a religion or a doctrine". Similarly, in the Vietnamese Dictionary by Van Tan (editor) (p. 427), belief means: "Belief in a religion: Freedom of belief". Thus, in the etymological of sense, the belief is the religious belief in every human being. However, to better understand the concept of belief, it is necessary to consider the following specific aspects:

\section{The Beliefs from the Perspective of Religious Studies and Anthropology:}

This group of views said that beliefs are the psychological state of people towards the sacred forces, which are part of religion and cannot be separated from religion, which is the basis for forming religion. In Vietnam, a representative of this group of views is Dang Nghiem Van (2005). In his work on Theory of religion and the situation of religion in Vietnam (2005), he analyzed quite clearly the concept of belief as a religious faith, beliefs are not completely separated from religion: "If you understand beliefs are beliefs that have a part outside of religion, if understood as religious beliefs (belief, believe, in a narrow sense, etc.), beliefs are only a major part of the religion" (Van, 2005, p. 106). The author also expressed his disagreement and suggested revisiting when considering religion and belief as two low and high levels are different. Because of the religious researcher had accepted that the decisive factor of religion was virtue faith or belief, it is the only measure of the inferiority of the religions in the community, and of believers with their religion. If cultural equality (including religion) is accepted, there is no appreciation of one religion over another (Van, 2005).

In particular, when referring to a concept used by many people as folk beliefs, he thought that this is a popular religion: "The term may be a way of understanding religion in the popular way, meaning customary, public opinion or engaging in rituals, not in the mainstream that comes primarily from, the study of doctrine, reflection and enlightenment. Or it can also be understood that the forms of national religion have been handed down from ancient times, close to the community such as festivals, pilgrimages, holidays with parades, dancing, even the divination form, general number, etc. though few believed but still participated. At festivals, processions, etc., it is still responded by the majority of the popular class in rural areas, according to a tradition that has long existed in the nation" (Van, 2005, p. 321).

\section{The Beliefs from a Cultural Perspective:}

In a work about religion in Vietnam, Le Nhu Hoa (2006) said that, in essence, beliefs, as well as religions, are a method of realizing and improving reality. The similarity between them and the improvement of reality. The differences between them are just historical features. There are 5 criteria for distinguishing beliefs and religions, namely: The source (beliefs only consist of spiritism, while religion in addition to spiritism also has totem or other supernatural theory); objects of worship (beliefs: All things spiritual, polytheistic, religious: Unity, only one god); methods of practice (beliefs: Magic; religion: Religious rituals); institutions (beliefs are not yet complete, religion is complete about material institutions, clergy, formal system, canon law, complete canonical, systematic scriptures, ethical beliefs, have community sentiment about belief); sphere of influence, social context (beliefs: Narrow, usually ethnic communities, in non-state societies; Religion: Wide, popular among ethnic, national, ethnic communities gender, in societies with a state).

The above assessment shows that both beliefs and religions are human creations. In the process of existence and development, people created beliefs and religions to make spiritual support for themself and the community. Over time, such creativity has become a traditional system of values, lifestyles on which people show their faith and values.

\section{The Folk Beliefs of Vietnamese People}

Vietnamese folk beliefs, also known as Vietnamese traditional beliefs, are indigenous beliefs of ethnic groups living on the Vietnamese territory through many generations.

Vietnamese folk beliefs believe that anything has a soul, so the ancient people worshiped a lot of gods, especially those related to agriculture such as heaven, moon, earth, forest, river, mountain, etc to be blessed. For ethnic 
minorities, each ethnic group has its own belief form. However, the most typical feature is that the original forms of beliefs and folk beliefs are still preserved among ethnic groups such as the Tay-Thai and Hmong-Dao groups; Hoa-San Diu-Ngai group; Cham-Ede-Gia Rai group; Mon-Khmer group.

Besides, one of the most common customs and practices of the Vietnamese and some other ethnic minorities is the ancestor worship and death anniversary of the deceased. In Vietnamese families, every family has an ancestor altar and commemoration, remembering the merits of the ancestors is very important. Besides ancestor worship in each family and clan, many villages in Vietnam have a communal house of worshiping tutelary gods. The custom of worshiping tutelary gods in village temples (Village's Tutelary god) is a unique feature of Vietnamese villages. The tutelary god worshiped in communal houses can be gods or outstanding figures with great merits such as the ancestors of a trade village or a national hero who had "founding the nation", opposing invaders.

For several centuries in Vietnam, Mother Goddess worship has been a source of strength, inspiration, and spirituality, particularly among working-class families. Along with the worship of ancestors, the belief of worshiping the Village tutelary gods, the worship of Mother Goddess has kept an important position in the spiritual life of the Vietnamese people.

For many Vietnamese, they believe in the existence of a soul (Roszko, 2012; Van, 2020). This belief goes from the belief that the soul only reaches its ultimate goal after many reincarnations, to the idea that life will now determine its final destiny. Consequently, one person can feel confident that he will eventually merge with the ultimate reality after death, others will surely reach Nirvana, and others will believe that he will be rewarded in heaven. From the faith and the punishment or the blessing of the soul has led to the worship of the souls of Vietnamese People.

Also, Vietnamese people also worship gods such as the kitchen god, the earth god, the river god, the mountain god, etc. All that worship has formed a system of Vietnamese folk beliefs extremely rich and diverse as we see it today.

\section{The Ancestor and Ancestor Worship}

\section{The Ancestor:}

According to the folk concept of the Vietnamese people, the ancestor is a term used to refer to people who have the same bloodline but have passed away such as grandparents, cavalry, grandparents, fathers, mothers, etc. people who have had success and nurtured, have a great influence on life living physically and spiritually of the generation who are living.

The primitive social ancestors have their roots in the totemism of the tribal clan (Tylor, 2002). The totems ancestors of the matriarchal period are objects that are in nature, have a close relationship with man, and when they are deified and sanctified they are considered the totems (totems) of the gens and tribes. During the patriarchal clan, the ancestors were the heads of the gens, tribes such as chiefs, military leaders, etc. powerful.

The ancestor in society has a division of class that is more fully expressed (Kim, 1919; Giau, 1973 \& 1983; Van, et. al, 2020). They are usually the holders of the position of head of the family, the right to inherit, and the wills of property recognized by law and society (Dai Viet Su Ky Toan Thu, 1697).

During the development of history, the concept of ancestor has also changed and developed. It is no longer limited only in the bloodline - family, clan, etc. but has expanded to the community and social scope. The formation and development of nations and peoples are often associated with the names of those who have created and preserved the community's life. They are heroes and celebrities who, when they live, are worshiped, respected, lost memorials, worshiped in religious spaces. In Vietnam, they are the ancestors of the profession, the village's Tutelary gods, national heroes, cultural celebrities, etc.

The Ancestor Worship: 
Ancestor worship is a conscious human activity, a complex whole of consciousness about ancestors, symbolism about ancestors, and rituals about "thờ" (worshiping) and "cúng" (offering).

"Thờ" (worshiping) is a factor of the awareness of ancestors, a feeling of gratitude, remembrance, the direction towards the origin, and the past. Ancestor worship is a show of respect, gratitude, and remembrance of the ancestors, at the same time it is also a show of faith in the protection, protection, and assistance of the ancestors. The basis of the formation of ancestral consciousness is the belief about the living ancestor's soul that can protect and bless the descendants. Ancestor symbol is the image of talented, merited, and virtuous people. On the altar of ancestors, there are usually plaques, statues, and pictures that are arranged elaborately and solemnly.

"Cúng" (offering) is a ceremonial element, is the practice of a series of movements (praying, prostrating, kneeling, bowing) of the patriarch, the patriarch. It is an activity in the form of a ceremony and is determined by the concept, customs, and practices of each community and ethnic group. The worship and an offering are two elements that interact and create a separate whole - that is, ancestor worship. The "Worshiping", is the content, and the activity of "Offering" is the expression form of the content of worship. The sense of worship, respect, gratitude, remembrance, hope for the help of the group. The first is the core content, the main thing that makes ancestor worship become ancestor worship. If there are no "thanks" but only "worshiping", the worship of ancestors without "sacred soul", without intrinsic attraction, can easily become bland and therefore, cannot be ancestor worship. The "offering" is just a form of expression, but it glorifies the sacred, mysterious, vague, and creates an attraction. It is the adhesive that creates colors to satisfy the belief of the worshiping subject.

In primitive society, the sense of ancestors was an element of primitive social consciousness, reflecting the inability of humans to face the force of nature (Taylor, 2000). Later, along with the natural force is a dominant force, such as oppression, exploiting class, etc. that always dominates the daily life of people. Stuck in real life, people seek liberation in spiritual life. Along with the symbols of the gods, the symbol of totem appeared in the matriarchal clan. The main feature of the ancestor worship in this period was the worship of totemism (Giau, 1973 \& 1983; Thinh, 2004).

Into the patriarchal clan, ancestral worship beliefs reflected the change in the social division of labor (Taylor, 2000). The man plays a key role in economic life. They are people who have both secular power, prestige, and the right to hold the worship of gods, including dead ancestors. Objects of worship in this period were transferred from totem ancestors to real ancestors, with the dead bloodline.

Thus, it can be seen that the objective deep social origin of ancestor worship is the limitation of the production force and the limitation in awareness; it bondage in the dual relationship between the human to nature and between humans and humans in society. Its direct, social origin is the division class in society, the consequence of which is the enhancement of the role of the head of the family - the gens. These people, relying on their prestige to consolidate and sanctify the ancestor worship that was in place during the matriarchal time (Thinh, 20004). In a caste society, the oppression, exploitation of class, social injustice have made people without a real way to seek the help of their ancestors, which are also important social sources give rise to ancestor worship. Along with that, human awareness is also an important source in the process of the formation and existence of ancestor worship. Primitive people believe that after death, the soul continues to live (Taylor, 2000). The concept of the soul is one of the basic elements located in the complexes, symbols of ancestors, and is a characteristic of ancestor worship. Another ideological element, somewhat older than the concept of the soul, influencing the development of ancestral symbols is the image of the totem ancestor, the image of the god that protects the family and the clan.

\section{RESEARCH CONTENT AND DISCUSSION}

\section{The Nature of Ancestor Worship Belief}

Marx \& Engels (1995, p. 279) pointed out, "religion is born in a very primitive age, out of the very false, primitive human conceptions of their own nature and of the natural world around them", that is also true of ancestor worship belief. Ancestor-worshiping ideology is built on materials that are childish and innocent conceptions about the 
souls of the dead, of the totem ancestors, of the gods that protect the family and the clan (Taylor, 2000). In addition, ancestor worship beliefs are formed on the basis of psychology and religious sentiments of individuals and communities in society.

Ancestor worship is formed on the basis of a belief in the immortality of ancestral spirits (Giau, 1973 \& 1983; Ngoc, 2002; Binh 2005, Van, 2020). That belief stems from an instinctive desire - the longing of man. It is a man who sanctifies love, an attitude of respect for people who are responsible for creating life. In life, people are not only in contact with the existence, but also in contact with the invisible, abstract, and ambiguous, only perceived by people, sensuous but cannot be explained by reason. The belief in the existence of ancestors contributes to balancing the psychological state, sometimes as the end, as the relief of human loneliness and unhappiness before death. Through ancestor worship, people show a way of thinking about death and life after death, releasing fear when facing it.

In the patriarchal system, the power of the patriarch, the patriarch, also gives rise to the feeling of fear and approval in descendants. This feeling is nurtured, passed down through generations, and even transferred to the afterlife with the idea that the dead can still punish their offspring. Ancestors like other gods can bring calamity to their descendants, so it is necessary to respect and worship regularly so that the ancestors will not harm, protect, protect, and help.

Ancestor worship also stems from the filial piety of the descendants. The relationship between parents living with children is the embodiment of the relationship between ancestors and descendants. The reverence of parents is followed by ancestor adoration. The duty of respecting, reporting filial piety, paying gratitude to the merits of living and nourishing, etc. parents' education is also the obligation to pay respect and gratitude to ancestors. Ancestor worship shows filial piety, respect, and gratitude to all those who have been born, nurtured, and formed for themselves. However, descendants are only tolerated and protected by the ancestors when living up to the wishes of the ancestors. On the other hand, children and grandchildren only respect, agree, and worship their ancestors when they deserve a good example for their descendants to follow. If anyone, in the past, acted against the interests of the clan community and family, not only was not respected, worshiped but also cursed and punished.

Ancestor worshiping beliefs are like other types of beliefs, other religions are a false reflection of reality, an illusory reflection - in people's minds - of forces outside the chi. to coordinate their daily life (Marx \& Engels, 1995). Foreign forces outside, here are ancestors in the invisible world. The lost ancestor is the object of reflection in order to satisfy and satisfy the spiritual shortage of the living. When the ancestors are not alive, they are "wise", when they die they are "sacred", they still live on the altar, both close and strange and holy. To respect our descendants and to worship our ancestors is to show our gratitude to our ancestors. The sense of ancestry is a sense of origin. Ancestor worship is a continuous reflection of the time, a bridge between the past, present, and future. Life is eternal, death is not the end. After generations, death is just the beginning of a new cycle of birth (Lang, 1974).

Ancestors are tied to supernatural powers; that is the sacralization. The sanctification derived from the concept of the immortality of the soul. The sacredization and sanctification of the ancestors are imagination but have roots in real life. The sense of ancestors to form and exist helps people to overcome the mundane, mundane life, promote exploration, overcome the existing state to move forward, and overcome the mental deficits. In terms of morality, the sense of ancestors has deep human value, it generates kindness in each person in the social community.

In addition to the symbol of the ancestral soul, totem ancestral symbol, the symbol of guardian gods is also the thought content of the consciousness of the ancestors. The concept of totem ancestors gives people a vague, strange, sacred image of their ancestors. And the concept of divine protection makes people feel reassuring.

In terms of epistemology, the subject of perception and reflection is the living person, the object perceived and reflected is the deceased ancestor. In terms of society, it is a reflection of the myth of the patriarchal authority, an inevitable result of the process of social differentiation, from matriarchy to patriarchy (Kim, 1919; Giau, 1973; 
Thu, 1997). The social nature of ancestral worship beliefs is clearly shown in the content, object, and form of reflection, determined by its social, cognitive, and psychological origins.

The most unique feature of ancestor worship is that it is a special form of social consciousness, a historical - social and cultural phenomenon in the spiritual life field, which is a reflection image of social existence, subject to the regulation of social existence, is relatively independent, formed very early and long-standing in society. The origin and nature of ancestral worship are intertwined, forming a distinctive feature of this type of belief.

It can be said that the human spiritual life when rebalanced has been expressed quite fully in ancestor worship, although this is never felt directly from these believers. For even many other beliefs as well as its higher form of religions there is not much mention of death; even for those who follow these beliefs or religions, the feeling of this is largely unrecognized, although as mentioned above in the religions always contains not only belief in immortality but it is also a mental preparation for man to cope with death. Ancestor worship, especially in ancient primitive times, partly helps people overcome suffering and fear of death (Taylor, 2000). This is the first point, the important content that ancestor worship brings to everyone, which is to build the strength to understand and overcome death.

In ancient Vietnamese society, when religions did not exist, they could not appear as in Western societies, the emergence of beliefs in general and ancestral worship in particular to seek protection from an afterlife world, the world of the dead, indirectly helps the living people feel comfort, encouragement in these difficult circumstances, helps them to face and overcome. With the belief in the help of a transcendent metaphysical ancestor, the practice of worshiping rituals has made living people feel the direction and attachment back to their predecessors as well as the protection they expect. After each such ceremony, for everyone, it is the return and restoration of beliefs, will, and the strongest motivations for life.

\section{The Value of Ancestor Worship Belief}

From the above analysis, we can see that the belief of ancestor worship is the concept of the existence of the soul and the relationship between the dead and the living (same bloodline) by the spiritual path. After death, ancestors will return to witness, monitor their descendants' behavior, rebuke, or bless their lives. In this belief, "when drinking water, remember its source", is the dominant content.

The principle of "drinking water, remember its source" expresses descendants' gratitude to those who were born when they died as well as when they were still alive. On the other hand, it also shows the continuity and enduring responsibility of descendants for the needs of their ancestors. Responsibility is manifested not only in living acts (preserving honor and continuing the traditions of family, lineages, and country) but also in specific acts of worship. A foreign scholar, when studying this belief in our country, commented: "Family members offering offerings are absolutely necessary for ancestral souls to have a peaceful rest in the afterlife" (Roszko, 2012).

Here, it is also necessary to mention the characteristics of "only love" rather than "rationality" of the Vietnamese people (Giau, 1973 \& 1983). Although many Eastern ethnic groups have an "only love" behavior, in Vietnamese people, this attitude is very broad and profound (not only for living people but also for people who are about to be born or dead). People are always under the influence of the concept of both expecting to receive "ancestral blessings", "living for the graves of the ancestor, whoever lives for the bowl of rice", and taking responsibility to give blessings to children and grandchildren". When worshiping ancestors, on the one hand, people look to the past, orient to the present (educate the family traditions, morals to be human for descendants), and on the other hand, prepare for the future. The generation line that is also the moral line will always continue to grow.

Ancestor worship is also a religious form that has great significance in terms of community organization in traditional society (Kim, 1919; Giau, 1973; Van, 1919). Living in society, on both the vertical and horizontal axis, people cannot live in isolation and alone. Along the longitudinal axis of patriarchy, ancestor worship is the continuity of generations: grandparents - parents - oneself. Each human being has the responsibility to worship the previous four generations: "cao" (great-great-grandparents), "tằng" (great-grandparents), "tổ" (grandparents), 
"khảo and tỷ" (parents) and they also believe that they will be commemorated by their descendants of the next four generations. According to the horizontal axis, ancestor worship has attached people in the kinship connection: father, mother, wife (or husband) as a collective - both living and dead are bound by blood and worshiping the same ancestor, the lineage has the power to ensure spiritual values for each of its members in the family and village.

The role of community association of ancestral worship is even clearer when we consider the issue of Hung Vuong (worship of King Hung - the ancestor of the nation). The entire Vietnamese community is underpinned by the common belief of a "fellow citizens" source, all of which are "son and children of Lac Hong". And that is also the strength that helps our people to be stable against all the threats of foreign invaders. "The Hung kings have built the country, our Uncle and grandchildren must keep the country together" (Minh, 1995). During the fifteenth and sixteenth centuries (Dai Viet Su Ky Toan Thu, 1697) until now, when Hung Vuong was considered the fatherland, this consciousness played a very important role in the spiritual life of the nation.

Ancestor worship has simple content and rich in practicality, not as extreme as many other religions (Gia, 1973 \& 1983; Ngoc, 2002; Hinh, 2007; Van et. al, 2020). Therefore, it is easily secularized to become a way of life, customs, deeply rooted in the subconscious of each person. By worshiping ancestors, the previous generation sets an example for the next generation not only because of the responsibility towards the parents but also for educating and teaching the descendants of the lineage. Professor Dao Duy Anh said: "To sacrifice ancestors is to use the maintenance of the race as the purpose" (Anh, 1998, p. 249). During the ceremony, their vows are simple, very practical: their prayers for protection and support for their daily lives are peaceful and smooth. It is not known how effective such a request is, but first of all, people feel spiritually peaceful, and an important spiritual fulcrum for life. In this worship has actually arisen a two-way relationship: the dead need the living's worship to be able to settle down in the afterlife, not become a wandering "hungry ghost", and the living only can be at peace and serene when being protected and mysteriously supported by the dead. The spirits of the elders are always by their side son and grandchildren, telling them and helping them have a good and harmonious life. With simple desires and primordial beliefs (Taylor, 2000), ancestor worship is considered to be a religion "just within reach" of all classes in terms of both ethical content and execution rituals. Therefore, the ability of this belief to spread in space and time is understandable.

Foreign religions, in order to survive in Vietnam, were forced to reconcile with the indigenous beliefs deeply rooted in the minds of the Vietnamese (Giau 1973 \& 1983). And the endogenous religions in the country such as Cao Dai religion and Hoa Hao religion in the South have known on the basis of ancestor worship. Not only religions but also in other folk beliefs such as worship of King Hung belief, worship of Mother Goddess belief, worship of Village's Tutelary god belief, etc., we can also see the impact of ancestral beliefs in the gratitude of roots. Originating from the god worshiping belief, Vietnamese people worship Mother (mother worship) with the desire to draw this god closer to the family belief, thereby having a close sympathy as between the protective mother and her children (Huy, 1995; Huu, 1996; Thinh, 2004).

It can be said that ancestor worship is a folk belief of the nation that originated from time immemorial and carries the nature of virtue of lovingly drinking water to remember its origin in the historical process, it has been fortified by other religious ideologies. Completely complementary to institutionalize a religion become Ancestors Grandparents religion (Giau 1973; Anh, 2005).

\section{Changes in Ancestor Worship Beliefs in the Current Period}

Since the country's reform (1986), all types of religions and beliefs are considered to have an opportunity to "rise" after a long sleep (Hinh, 2007; Van, et. al, 2020). Religious and belief life became active. Religious worshiping facilities are increasingly built and renovated more spacious. Along with it, the number of devotees attending various types of religious services has also increased (Government Committee for Religious Affairs, 2016). Ancestor worship is also immersed in that general trend. Ancestor worship in families is also increasingly focused. If religion only meets the spiritual needs of a part of the people who are followers of that religion, ancestor worship 
meets the spiritual needs of the majority of Vietnamese (San, 1998; Ngoc, 2002; Hinh, 2007). If in the past, we still encountered families that did not have an ancestral altar in their home, today every home doe. Along with the economic development, small churches or incense bowls placed temporarily on the roofs of the subsidized time are gradually replaced by fixed altars with many solemn and beautiful designs. The position of the ancestral altar is also focused. Today, to place an altar, people no longer arbitrarily place as before but need to see the altar direction, the size of the altar in terms of height, length, and width. The date of placing the altar or picking up the incense bowl is also an important family event. For families with conditions, people often reserve a private room, on the top floor, or the cleanest and most formal area in the house as a shrine room. The change in the way of arranging incense bowls and ancestral worship space in today's families is a clear indication of the importance of ancestor worship in contemporary Vietnamese people spiritual life.

The importance of ancestor worship in addition to the manifestation through ancestral worship space in the family is also reflected in the focus on building the system of ancestral churches, clan churches. In recent years, many churches have been renovated and rebuilt. Many families contribute up to a few billion VND to build their churches and their churches (Government Committee for Religious Affairs, 2019).

The trend of building ethnic churches has been restored, but the trend of personalizing ancestor worship has also developed very strongly (Van, 2019). The personalization that we mention here refers to the trend of ancestor worship today transferred into each family member. In the past, ancestor worship was concentrated in the patriarchal family (head of the clan, head of the family, chief of the branch, and eldest son), now, all family members worship ancestors in their own family. Many families still maintain the custom of focusing on the Lunar New Year's death anniversary and focusing on the eldest son's house to make death anniversary. However, in many families, the anniversary is no longer the day the children gather as before. The community-based commemorative form of commemoration of family members is transformed into an individual death commemoration form. Each family member performs the death anniversary ceremony at his home. Thus, if a father has 7 children when the father dies if, in the previous form of commemoration, the children will gather at the eldest son's house to worship his father's death anniversary. Not only the eldest son's own home, even all 7 children, regardless of boy or girl, will carry out the father's death ceremony in their own home. If he thinks that the deceased can return to enjoy the sacrifices of his relatives on the anniversary of the death, this father will have to go to 7 houses to enjoy 7 trays instead of one as before. Is it true that the development of the nuclear family model has affected the change in the way of ancestor worship as above? Or is it the manifestation of the urban lifestyle in modern society, where direct human communication space tends to be narrowed? (Van, 2005; Van, 2019).

The way of arranging the ancestor altar and the clan worship committee has also changed many times. The book of Vietnamese customs by Phan Ke Binh $(2005$, p. 346) describes the worshiping in the past in the church as follows: "The ancestral church has its own altar and tablet to worship forever, never change", it is called "bách thế bất diêu chi chủ" (the ancestors are eternal and holy). As for the rich family, there is enough ancestor of four generations: "cao" (great-great-grandparents), "tằng" (great-grandparents), "tổ" (grandparents), "khảo and tỷ" (parents). The tablet of the ancestor of four generations is made of applewood, which means that the wood is a thousand years old; one meter long, in the middle of the name, surname, title and on both sides, the date of the ancestors' birth and death, covered by a square box and kept in mosaic when the offering is to take off the towel. By the fifth generation, descendants will bring the tablet of "cao" to bury ("thần chủ" - god owner). That act is called "ngũ đại mai thần chủ" (children, grandchildren only worship the ancestors of four generations in the church of the clan). After the activity of "ngũ đại mai thần chủ", tablet of "cao" is buried, "tằng" will be raised to "cao", "tổ" will be pushed up to make "tằng", "khảo" will be pushed to "tổ". Just like that, only four generations were worshiped in the family church.

Today, this form of worship is maintained by very few families. Most of the altar of ancestor worshiping, especially the ancestral altar in the city, have no god, there is no god of worship, and there are no altar of "cao", "tằng", "tổ", have only altar of "khảo" (parents). A few families more in the countryside still keep the god owner, some families cannot keep the god owner but still Long is inlaid on the altar. Therefore, the method of worshiping 
"ngũ đại mai thần chủ" is no longer maintained. Without god owner, there is no tablet of the "cao", "tằng", "tổ", so now people no longer have the concept of worshiping ancestors in five generations. Those families who are still fortunate enough to retain the ancestral cards from the past are forever kept, regardless of the 5th generation, they must replace the new generation tomorrow, and the ancestral tablet is called as a treasure that needs to be preserved.

If in the past, worship tablets used apple wood, now people prefer jackfruit wood. We asked those who made worshiping in Son Dong village, Ha Tay (Hanoi today), a village famous for its profession of worshiping worship, to know: "The worship, the statue made of jackfruit wood will be more sacred". Why is sacred, no one explains.

The usual pattern of an ancestral altar today in families is a shrine on which incense bowls are displayed. The Ancestor Worshiping Committee is also the Goddess that governs the house, so a current ancestor worshiping board is usually arranged with 3 incense bowls. The largest bowl in the middle is worshiping the gods; the second big right bowl is dedicated to the family line, regardless of paternal side (husband's), maternal side (wife's); the smaller left bowl worships the young lost (aunts, grandparents) of the lineage. There are also other furnishing families, including a bowl of divine incense; on the right is the incense bowl worshiping the inner side; on the left is the incense bowl to worship on the outside, etc. There are currently no standards for ancestral altar decoration.

The emphasis on ancestor worship today is also reflected in the emphasis on clan graves. For ages, ancestral tombs are always respected and preserved by descendants. There is a proverb that "keeps as keeping the ancestor graves". The proverb has shown the importance of ancestral graves for the living. However, in our opinion, there have been many manifestations of a bit over-emphasis on ancestral graves in today's society. The family raced to build their own grave to be really big and beautiful. The tomb is the house of the deceased. The fact that the descendants build for the ancestors a new house, a beautiful house is a cultural beauty, but racing to build a grave so that their tomb must be big and beautiful than others is a matter of thinking. At the moment, no one has ever proven that a big tomb is a great blessing, a small one is a small blessing. It is the desire that our tomb must be better than another one that we see nowadays, many cemeteries appear where the graves are built together, causing the children to come to burn incense and have no place to stand and go to the grave of their house. On a business trip in Hue, we were fortunate enough to be taken by a local religious official to visit the mausoleum city. We were really overwhelmed with the large house tombs built on an area of hundreds of square meters with the cost of having mausoleums up to several billion VND. Local people said this area almost every home has people currently residing in the US. The descendants who work far away do quite well, remember the merit of their ancestors sending money to build ancestors' tombs. Just like that, the house built later wants our house to be bigger, more beautiful, and cost more to build than the previous one. Having a house that has just been built, it costs five hundred million VND, but next year, seeing a neighbor's house building bigger than the cost of one billion VND, the dam will be built to build a bigger hybrid with higher cost. The mausoleum city, also known as the city of the dead, has been visited by many Korean, Taiwanese, and Japanese visitors about the current Vietnamese ancestor worship model.

Taking care of ancestral graves is a traditional Vietnamese culture, but perhaps it is not necessary to compete like that. Many families have fallen into difficult economic situations, and brothers disagree with their significant contributions to the construction of such tombs and churches. Just as author Phan Ke Binh (2005) said, we need to find a way to avoid waste and trouble for loved ones who are living, then perhaps we will also agree with our ancestors.

\section{CONCLUSION}

In fact, the important influence of religions and beliefs appeared throughout the history of more than two thousand years, in the development of most societies in the world. In the West, Christianity, a highly organized religion, helped shape medieval European society after the fall of the Roman Empire at the end of the 5th century until the pre-capitalist era XIV. In East Asia, religion cannot appear, has a strong influence on society, except Shintoism in Japan. Instead, we see the emergence of different types of beliefs that govern the spiritual life of social people, 
including ancestor worship. Ancestor worship belief has become a component of Vietnamese culture for a long time with its own identity, characteristics, and strength when compared with Western and Arab societies. Researching, understanding as well as promoting positively and negatively limiting this belief in current Vietnamese society needs to be paid attention, even though ancestral worship itself is a culture process, endogenous is difficult to change by individuals or the whole society.

Thus, it can be said that ancestor worship is a type of folk belief, associated with cultural and ethical practices on the basis of the belief that dead ancestors will protect and protect, helping children and grandchildren is a reflection of the patriarchal power myth and is expressed through worshiping rites according to the conception, customs and practices of each person, each family and each village commune community.

Over time, ancestral worship beliefs have constantly changed, including both positive and negative. The change is shown in many ways such as the way of worship, the content of worship, and the ideas that the ancestors bring to their descendants. In this article, we have not had the opportunity to mention the change of faith in the ancestor worship of the Vietnamese people. Hope to have the opportunity to study the occasion in the next research articles.

\section{REFERENCES}

1. Anh, D. D. (1998). Vietnamese Cultural and Historical. Dong Thap: Đong Thap Universal.

2. Anh, T. (2005). The Custom of Worshiping in Families and Public Places in Vietnam. Hanoi: Youth.

3. Binh, P. K. (2005). Vietnamese Custom. Hanoi: Culture Information.

4. Chu, P. H. (1992). Least-Year Charter Schedule. Hanoi: Social Science.

5. Duy, N. D. (2002). Spiritual Culture. Hanoi: Culture Information.

6. Dai Viet Su Ky Toan Thu. (1697) (translation: 2004). Vol 1. Hanoi: Social Science.

7. Dai Viet Su Ky Toan Thu. (1697) (translation: 2004). Vol 2. Hanoi: Social Science.

8. General Statistics Office. (2019). Results of the Population and Housing Census in 2019. Hanoi: Statistics.

9. Government Committee for Religious Affairs. (2016). Beliefs, Religions and Decrees detail a number of articles and measures to enforce the Law on Beliefs and Religions. Hanoi: Religions.

10. Government Committee for Religious Affairs. (2019). Vietnam's Religious Situation. Hanoi: Religions.

11. Giau, T. V. (1973). The Development of Thought in Vietnam from the Nineteenth Century to the August Revolution. Hanoi: Social Sience.

12. Giau, T. V. (1983). Traditional Spiritual Values of the Vietnamese Nation. Vietnam: Ho Chi Minh City.

13. Kim, T. T. (1919). A Brief History of Vietnam. Quan Hai Tung Thu

14. Hinh, N. D. (2007). Vietnamese Spirituality. Hanoi: Encyclopedia Dictionary.

15. Hoa, L. N. (2006). Nature of Beliefs and Religions. Hanoi: Religions

16. Huong, N. X. (2009). Beliefs of Coastal Residents in Quang Nam - Da Nang. Hanoi: Encyclopedia \& Cultural Institute.

17. Huy, C. X. (1995). The Oriental Ideology with Suggestion of Reference Viewpoints. Hanoi: Literature.

18. Huyen, N. V. (1995). Contributing to the Study of Vietnamese Culture, Vol 1. Hanoi: Social Sciences.

19. Huu, T. D. (1996). Come Modern from Tradition. Hanoi: Culture.

20. Institute of History. (2007). Vietnamese History. Vol 3. Hanoi: Social Sciences

21. Karl Marx \& Friedrich Engels. (1995, trants). Complete Episode. Episode 21. Hanoi: National Political

22. Lang, N. (1974). Vietnam Buddhism History. Saigon: La Boi.

23. Ngoc, P. (2002). Vietnamese Cultural Identity. Hanoi: Literature.

24. Roszko, Edyta. (2012). From Spiritual Homes to National Shrines: Religious Traditions and NationBuilding in Vietnam. East Asia 29: 25-41. Doi: 10.1007/s12140-011-9156-X

25. San, N. M. (1998). Access to Vietnamese folk beliefs. Hanoi: Ethnic Culture.

26. Tan, V. (1991). Vietnamese Dictionary. Hanoi: Social Sciences

27. Thinh, N. D. (2004). Worship of Mother Goddess and Shamanism among Ethnic Groups in Vietnam and Asia. Hanoi: Social Sciences 
28. Thu, N. T. (1997). The Influence of Ideologies and Religions on Vietnamese People Today. Hanoi: National politics.

29. Tylor, E. B. (2000). Original Culture. Hanoi: Art and Culture.

30. Van, V. H. (2020). From the Belief of the Immortality of the Soul, the Blessing or the Harassing of the Soul towards People to the Worship of the Souls of Vietnamese People. Asian Social Science 16 (3), 1 11. https://doi.org/10.5539/ass.v16n3p1

31. Van, D. N. (2005). Theory of religion and the situation of religion in Vietnam. Hanoi: National Politics

32. Van, V. H., Long, N. T., Thanh, T. T., Dong, T. K., \& Luong, P. V., (2020). Folk Beliefs of Vietnamese People. India - United Kingdom: Book Publisher International. DOI: 10.9734/bpi/mono/978-93-8981692-1

33. Vuong, T. Q., \&Tan, H. V. (1960). History of Vietnamese Feudalism. Vol 1. Hanoi: Education.

34. Vuong, T. Q., \& Tan, H. V. (1960). History of Vietnamese Feudalism. Vol 2. Hanoi: Education. 